\title{
Students' Experience on Their Communicative Learning Teaching in English Speaking Class
}

\author{
Aslinda Abas, Hadijah Jaffri* \\ Faculty of Education (Educational Psychology), University Teknologi Malaysia, 81310 UTM Johor Bahru, Johor, Malaysia \\ *Corresponding author: hadijahjaffri@utm.my
}

\begin{abstract}
This study aims to determine the effectiveness of activities such as oral presentations, role play and group discussions in students' achievement. The implementation of oral teaching activities have been carried out within the timeframe set by the researchers to study if there is a connection between these activities and the achievement of MUET Speaking among students in Maahad Johor. The combinations of quantitative and qualitative methods were used with the involvement of 70 samples completed a questionnaire for the quantitative data. Through pilot tests conducted, items used in the questionnaire over the validity of the set (>0.6). The results showed that there was no relationship between oral activities conducted and the achievement in MUET Speaking among students in Maahad Johor with $p=0,962$, which is more than the value of $\alpha=0.05$. In order to confirm this finding, the researcher then used interview sessions to obtain information in details. Results of interviews with 4 respondents found that they gave a very positive opinion on those oral activities that have been carried out. According to them, they have learnt several Speaking methods, but its effectiveness has not been seen in the achievement of MUET Speaking. Therefore, some recommendations have been listed in improving the achievement of MUET Speaking in the future.
\end{abstract}

Keywords: Perception; Communicative Language Teaching (CLT); MUET speaking; achievement

(C) 2017 Penerbit UTM Press. All rights reserved

\subsection{INTRODUCTION}

In the area of globalization, language is considered as an important means of communication among people who have different background and proficiency. In this era, English is regarded as important medium of communication. In Malaysia, it is perceived that English is being taught in Malaysia in all schools and universities where people almost speak everywhere and every day through it.

According to Gert and Hans (2008), speaking is speech or utterances with the purpose of having intention to be recognized by speaker and the receiver processes the statements in order to recognize their intentions. Brown and Yule (1999) stated that speaking is depending on the complexity of the information to be communicated; however, the speaker sometimes finds it difficult to clarify what they want to say. Rebecca (2006) stated that speaking is the first mode in which children acquire language, it is part of the daily involvement of most people with language activities, and it is the prime motor of language change. Thus, the ever-growing need for good communication skills in English has created a huge demand for English teaching around the world. Millions of people today want to improve their command of English or to ensure that their children achieve a good command of English. And opportunities to learn English are provided in many different ways such as through formal instruction, travel, and study abroad, as well as through the media and the Internet. The worldwide demand for English has created an enormous demand for quality language teaching and language teaching materials and resources.

In Malaysian Education System, the introduction of the Malaysian University English Test (MUET) has outlined speaking skills and strategies to evaluate students' speaking proficiency. Based on the MUET booklet of Regulations, Test Specifications, Test Format And Sample Questions which has been printed and distributed by Malaysian Examination Council (2006), MUET Speaking tests students on communicative skills, observing social conventions, conveying facts, managing a discussion, seeking and giving information, expressing disagreement, making suggestions and recommendations and others. There are two parts to the speaking component, an individual presentation (Task A) and group discussion (Task B). Task A requires candidates to convey facts, to explain, express preferences and to make decisions. Task B tests the ability of the candidates to interact and take turns, to negotiate meaning, to manage discussion and to close the discussion.

Thus, based on the above explanation, teachers including researcher try to find any new methods and strategies to improve students' speaking skills. In this research, the researcher would like to investigate how the use of communicative learning teaching (CLT) activities through role play, presentation and discussion are seen to promote and improve the use of English proficiency especially in speaking skills among Form 6 students of Sijil Tinggi Agama Malaysia (STAM) candidates in Malaysian University English Test (MUET) class. An outline of the Speaking skills is based on MUET Speaking Test Specification. According to Richard (2006), communicative language teaching (CLT) can be understood as a set of principles about the goals of language teaching, how learners learn a language, the kinds of classroom 
activities that best facilitate learning, and the roles of teachers and learners in the classroom. The study was also conducted to find out the perceptions and achievement of the students in reflecting to activities in communicative learning teaching (CLT). It is important to have knowledge of their beliefs and ideas about how English language should be learned. Since there are various skill in language learning, the STAM candidates' perceptions of the various activities implemented to carry out their skills will determine their preferences and achievements.

\subsection{THEORETICAL FOUNDATION OF THE STUDY}

As to meet the standard of education, Communicative Language Teaching (CLT) Approach has been applauded by many as one of the effective approach to enhance students' communicative competence. This is so, as the principles that underlie the approach focus on enhancing one's communicative competence in using English for various purposes in various settings with various speech communities. In fact, since late 1970's, Malaysia has adopted a communicative approach in the teaching of English as a second language to replace the structural-situational syllabus of English, where the communicative syllabus was fully implemented in the upper secondary schools in 1977 (Chan \& Tan, 2006).

However, after a number of years learning English in school as a compulsory subject, the low performance of the second language learners, especially in oral communication, still remains a problem, yet, to be solved. This calls for an understanding of the form six students' perceptions on communicative learning language, as they are the targets of implementation of various teaching approaches in language learning. As such, the perceptions of students regarding the effectiveness of the Communicative Learning Teaching (CLT) activities in second language classrooms need to be examined, as it will contribute to a good result in Malaysian University English Test (MUET) especially in speaking component. As claimed by Sato and Kleinsasser (1999), they stated that those who do not have a thorough understanding of CLT can hardly develop practices appropriate to the learning context, thus they easily return to traditional teaching. Hence, the researcher is interested to know how the communicative learning teaching (CLT) activities such as role play, presentation and discussion would assist students to get better grade during the Speaking MUET Assessment. Students' perception should be analysed as these will help the researcher to choose the best activities based on different level of proficiency among students.

\subsection{Communicative Learning Teaching (CLT)}

Communicative Language Teaching is most often defined as a list of general principles or features. One of the most recognized of these lists is David Nunan's (1991) five features of Communicative Language Teaching:

- $\quad$ an emphasis on learning to communicate through interaction in the target language,

- the introduction of authentic texts into the learning situation,

- the provision of opportunities for learners to focus, not only on language but also on the learning management process,

- $\quad$ an enhancement of the learner's own personal experiences as important contributing elements to classroom learning

- $\quad$ an attempt to link classroom language learning with language activities outside the classroom.

\subsection{Role-play}

Role-play is any speaking activity when students either put themselves into somebody else's shoes, or when they stay in their own shoes but put themselves into an imaginary situation. The joy of role-play is that students can 'become' anyone they like for a short time.

\subsection{Presentation}

A presentation is the process of presenting a topic to an audience. It is typically a demonstration, lecture or speech meant to inform, persuade, or build good will. The term can also be used for a formal or ritualized introduction or offering, as with the presentation of a debutante.

\subsection{Group Discussion}

Discussions in the classroom can lead to greater student understanding but this does not automatically happen. Discussions can be fruitful when the teacher is clear on the reasons for conducting discussions, adopts approaches for making the discussions productive, and is comfortable with the various roles the teacher must play in discussions.

\subsection{Significance of the study}

This study is expected to help the schools to improve students' proficiency in English especially in MUET speaking as a secondary language. Improving English is one way to help religious schools such as Maahad Johor to be more competent in society. The significance of this study are as follows:

2.5.1 The findings of this research would make it possible to find out the kind of Communicative Learning Teaching activities for form 6 students at Maahad Johor as STAM and MUET candidates, and their views on how they go about learning English.

2.5.2 Investigating students' perception on preferences on communicative learning language will provide teachers with the learners' views on effective teaching methods. It can thus be a source of the activities the teachers organise to help them learn.

2.5.3 Teachers will be able to come up with more interesting Communicative Learning Teaching activities to help students in improving their English proficiency in MUET Speaking. 
2.5.4 Identifying students' perception from different proficiency level will be able to guide teachers in preparing different level of activities for different class.

2.5.5 Students can experience variety activities in CLT as a medium to practise English inside and outside the classroom. This is a great chance for students to build up their confidence level.

\subsection{CONCEPTUAL FRAMEWORK}

The conceptual framework in Figure 1 explains the basic form of the research where MUET Speaking Test Specification has been listed as a course outline. Based on Speaking Skills listed in MUET Speaking Test and Specification, Communicative Learning Teaching activities (role play, presentation and discussion) will be conducted from February to June to assist and guide students in MUET Speaking test to know the effectiveness of CLT activities, MUET Speaking Assessment will be used as an indicator. Apart from that, students' perception on Communicative Learning Teaching (CLT) activities will be surveyed as these determine feedback from different gender and different level of proficiency. This study is expected to help the schools to improve students' proficiency in English especially in MUET speaking as a secondary language. Improving English is one way to help religious schools such as Maahad Johor to be more competent in society.

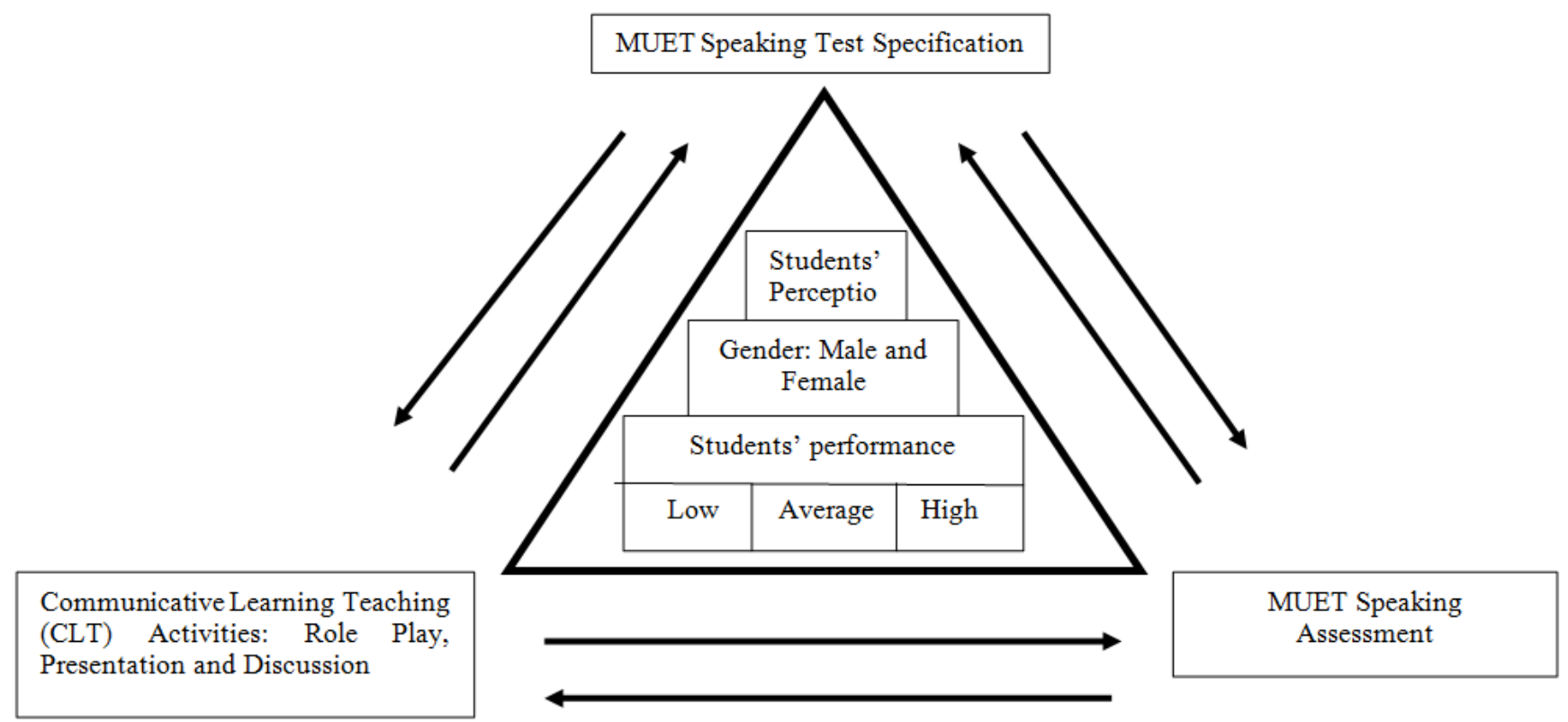

Figure 1 Conceptual framework of student's perception on clt activities in determining muet speaking assessment

\subsection{Theory of Communicative Language Teaching}

Communicative approach in language teaching starts from a theory of language as communication. According to Richard and Rodger (1999) the goal of language teaching is to develop communicative competence. CLT is the name which was given to a set of beliefs which included not only a re-examination of what aspect of language to teach, but also in a shift in emphasis in how to teach. The "what to teach" aspect of the communicative approach stressed the significance of language function rather than focusing solely on grammar and vocabulary. A guiding principle was to train students to use these language forms appropriately in variety of context and for a variety of purposes. The "how to teach aspect" of communicative approach is closely related to the idea that language learning will take care of its self and that plentiful exposure to language in use and plenty of opportunities to use it are vitally important for students' development and skill as reported by Harmer (1998).

CLT aims to make communicative competence as the goal of language teaching and to develop techniques and procedures for teaching language skills that are based on interdependent aspects of language and communication. Communicative competence includes grammatical competence, sociolinguistic, and strategies. Communicative language abilities include knowledge or competence and proficiency in the application of these competencies in the communicative use of language, contextual, and appropriate.

\subsection{Teaching and Learning Activities in Communicative Language Teaching}

For more than thirty years, much emphasis has been put on the teaching of English language using a communicative approach, which since its introduction in the early 1970s, has been defined, described, developed and used in a second language teaching and learning context to develop a learner's communicative competence. Communicative competence was a term coined by Dell Hymes (1972), to refer to the social and functional aspects of our ability to convey and interpret message and to negotiate meanings interpersonally within a specific context, where the focus is not only to develop the grammatical knowledge of language, but also to know when, where and to whom to use appropriate language in a communicative event (Richards, 2003). 


\subsection{Role of Teachers And Students}

Researchers have identified that the role of students and teachers in a communicative classroom as a very important issue. The goal of CLT is to communicate. According to Richards and Rodgers (2001) the role of learners in CLT methodologies is a joint responsibility of both the listener and speaker, which leads to being able to communicate in the target language. Therefore, the student's role within CLT is that of a negotiator, one who interacts within the group, and within the classroom procedure and the activities which the group undertakes. CLT aims to develop student autonomy through different activities, and thereby supports student centredness. Sung (2010) suggests that the information about students' needs in a particular teaching context is important when designing a CLT based programme, because a CLT based curriculum focuses on learner needs. Nunan (1988) also states that the learner centred curriculum focuses on subjective learner needs, as well as establishing a relationship between teachers and learners. He believes that learner needs should dictate the selection of content and methodology. He also points out that the potential conflict between teacher and students in relation to learning activities and materials are included in the methodology. Whereas conflicts are created on the basis of the teacher's superiority in a teacher centred classroom, the conflicts are negotiated through discussion and consultation between the two parties in a CLT classroom (Nunan, 1988).

To identify the role of a teacher in a communicative classroom, Brown (2007) defines the teacher's role as a facilitator, rather than a transmitter of knowledge, who values the students' linguistic development. Breen and Cadlin (1980) state that a teacher is an independent participant within the large learning group in the classroom. In relation to the use of language in a communicative classroom, Littlewood, (1981) maintains that the communicative language teacher favours the use of the target language, thinking that learners' mother tongue use tends to devalue the target language learning. Similarly, Richards and Rodgers, (2001) claim that teacher should use the target language from the very beginning of the language teaching to help students to communicate in a meaningful way.

\subsection{Assessment of Students' Performance}

Assessment is another major issue while practising any method. One of the purposes of assessment is to determine whether the objective of a course of instruction has been achieved or not. When it is identified that the objective of the course has not been achieved, it is necessary to evaluate this to establish the reasons behind it. In a traditional curriculum, assessment is often done by testing or an examination which happens at the end of the learning process. In a student centred curriculum, in contrast, assessment often takes place in the form of informal monitoring of participants' involvement in the teaching learning process. In other words, while a traditional curriculum focuses on summative assessment, a student-centred curriculum often depends on formative assessment (Nunan, 1988). The literature suggests that as CLT supports the student centred classroom, formative assessment is recommended. MUET Speaking result will be used as the real assessment in this study.

\subsection{METHODOLOGY}

\subsection{Research Design}

To explore students' experience on their communicative learning teaching activities in English speaking class, the researcher uses an explanatory sequential mixed method design. According to Creswell (2012), this design consists of first collecting quantitative data and then collecting qualitative data to help explain or elaborate on the quantitative results. The rationale for this approach is that the quantitative data and results provide a general picture of the research problem, which more analysis, specifically through qualitative data collection, is needed to refine, extend, or explain the general picture. Based on figure 2, a questionnaire and a structured interview were used in the study. The questionnaire was the main instrument and interviews were used to verify the quantitative data.

This design has the advantage of clearly identified quantitative and qualitative parts, an advantage for readers as well as for those designing and conducting the study. The researcher also captures the best of both quantitative and qualitative data to obtain quantitative results from a population in the first phase, and then refine phase. The difficulty in using this design, however, is that the researcher needs to determine what aspect of the quantitative results to follow up on. This follow-up means deciding on the participants to sample in the second qualitative phase as well as the questions to ask in this follow-up phase that builds on the initial quantitative phase. 

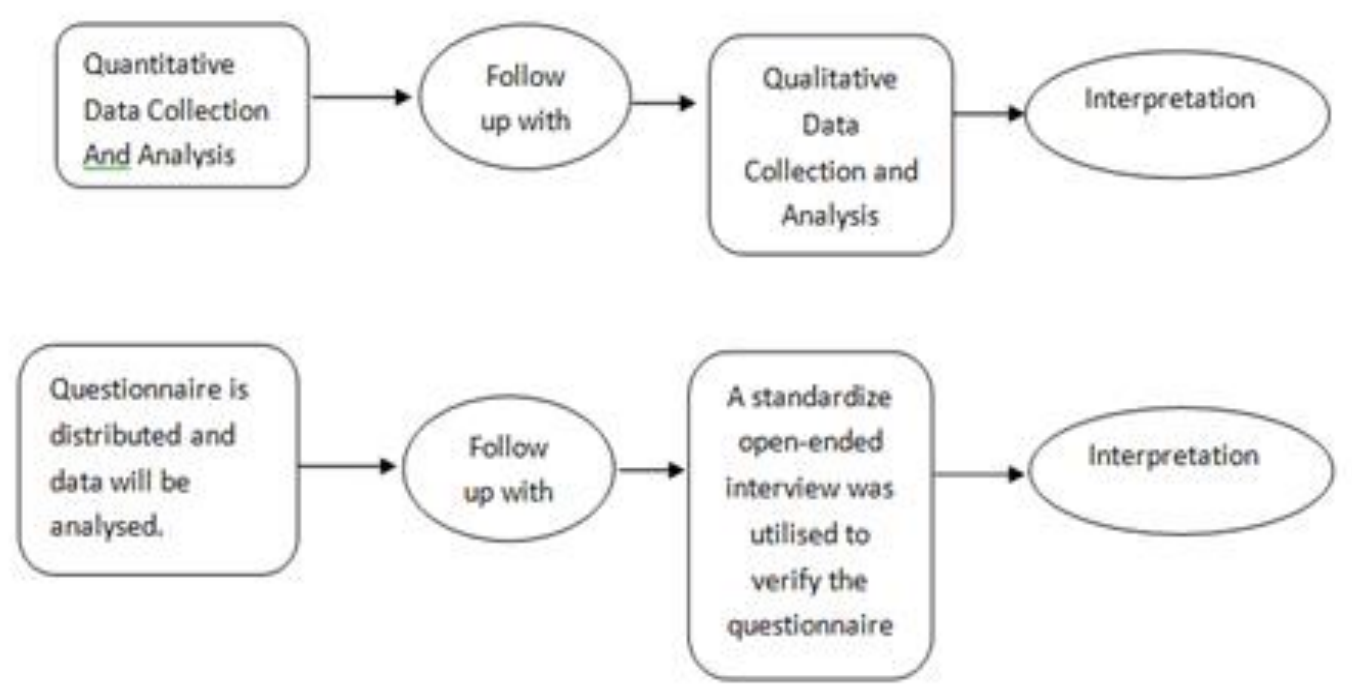

Figure 2 Explanatory sequential design (Creswell and Plano Clark, 2011)

This design has the advantage of clearly identified quantitative and qualitative parts, an advantage for readers as well as for those designing and conducting the study. The researcher also captures the best of both quantitative and qualitative data to obtain quantitative results from a population in the first phase, and then refine phase. The difficulty in using this design, however, is that the researcher needs to determine what aspect of the quantitative results to follow up on. This follow-up means deciding on the participants to sample in the second qualitative phase as well as the questions to ask in this follow-up phase that builds on the initial quantitative phase.

\subsection{Research Instrument and Participants}

Research sample in this study involved 150 students of Maahad Johor from different gender and different proficiency levels. While six subjects with different proficiency levels were chosen for the interview session after the questionnaire data has been verified. The researcher makes sure that all respondents have gone through CLT activities implemented in the class for four months. the lesson from February to June. The three activities which have been practised during MUET Speaking Class are role-play, presentation and discussion. After four months, the researcher fixed a one-period English lesson for the questionnaire survey to be conducted by her. A $100 \%$ return of questionnaire distributed was obtained. The questionnaire survey was then analyzed. Structured interview questions that would verify the findings were formulated, translated and pilot tested on 3 students. 6 subjects were identified for the interview. The subjects were interviewed individually by the researcher over a span of 2 weeks. Each interview lasted between 10 to 15 minutes. All interviews were audio-taped. A standardized open-ended interview was utilised to supplement and verify the questionnaire data.

\subsection{Research Sample}

Research sample in this study involved 150 students of Maahad Johor from different gender and different proficiency levels. While six subjects with different proficiency levels were chosen for the interview session after the questionnaire data has been verified. Table 1 shows the research sample for this study:

Table 1 Information of research sample

\begin{tabular}{|l|l|c|}
\hline Mix-methods design & Instrument & Number of respondents \\
\hline Quantitative & $\begin{array}{l}\text { Questionnaire } \\
\text { (40 items) }\end{array}$ & 70 students \\
\hline Qualitative & $\begin{array}{l}\text { Interview } \\
\text { Open-ended interview } \\
\text { (7 Questions) }\end{array}$ & 4 students \\
\hline
\end{tabular}

\subsection{Research Procedure}

First and foremost, the researcher makes sure that all respondents have gone through CLT activities implemented in the class during the lesson from February to June. The three activities which have been practised during MUET Speaking Class are role-play, presentation and discussion. In August, classes for the study were identified and the researcher fixed a one-period English lesson for the questionnaire survey to be conducted by her. A $100 \%$ return of questionnaire distributed was obtained. The questionnaire survey was then analyzed. Structured interview questions that would verify the findings were formulated, translated and pilot tested on 3 students. 6 subjects were identified for 
the interview. The subjects were interviewed individually by the researcher over a span of 2 weeks. Each interview lasted between 10 to 15 minutes. All interviews were audio-taped. A standardized open-ended interview was utilised to supplement and verify the questionnaire data.

After the researcher analyzing data for the questionnaire, the researcher comes up with the interview session. First of all, the researchers choose a setting with little distraction which is in her room. Secondly, the researcher explains the purpose of the interview which is to know the students' perception on communicative teaching activities. The respondents also were told that the interview session takes for about 10 minutes. The researcher used standardized, open-ended interview because she wants the same open-ended questions are asked to all interviewees. Thus, this approach facilitates faster interviews that can be more easily analyzed and compared.

\subsection{Data Analysis}

Researchers will always ensure questionnaires which have been distributed to respondents will be collected for analysis and interpretation. Data and information collected from respondents will be collected and reviewed in advance to ensure it has been completed correctly. If there is a questionnaire that is damaged or incomplete, the researchers will not process it.

In this study, researchers at first will collect and analyze information using quantitative methods. Raw data collected will be divided into two parts, Part A and Part B where Part A is the study of demographic information such as gender, age, class and English SPM results. Data were analyzed using statistical methods to find the frequency and percentage. The findings in Part B will be analyzed in terms of frequency, percentage and mean values in this study.

Once the data has been analyzed, the researcher will come up with a standardized open-ended interview to verify the questionnaire data. An assessment of MUET Speaking will be used to determine whether the CLT activities which have been practised in the class have helped them in communication skills. The raw scores of the respondents through questionnaire were analysed using SPSS for Windows Version 14.0. Two statistical measures were used in the analysis of data, namely mean scores and analysis of variance (ANOVA). To check the normality of data, homogeneity of variance was undertaken. ANOVA was used to compare the mean differences between groups. In the analysis of data, only mean scores that were significant were discussed. The significance level was set at $\mathrm{p}<0.05$. For differences in proficiency levels, Post Hoc Tests were used to determine significance between groups since more than two groups of subjects (low, average and high) were involved in each case. Finally the findings of the interviews were used to verify the quantitative findings where relevant. The use tapes records the entire interview, and then transcribe the text word for word. The transcribed text then becomes the data that are analyzed.

\subsection{RESULTS AND DISCUSSION}

\subsection{Quantitative Finding}

In order to answer the objectives of the research, the researcher has analyzed data through questionnaires and interviews. For quantitative data, the analysis which have been used are descriptive and inferential (correlation, ANOVA and T-test). The first objective is to compare whether Maahad Johor male students have different perception of four communicative learning teaching activities (speaking, role play, presentation and discussion from female students. There are four analysis for this objective. For significant differences between gender and speaking, the value of $\mathrm{p}$ is 0.04 , lower than the value of $\alpha=0.05$. Hence, the null hypothesis is rejected. This shows that there is significant differences in the level of $\mathrm{p}>0.05$ between speaking and gender. This implies that speaking is determined by gender. The mean for male (3.79) is lower than the mean for female (4.03), thus, it shows that female better in speaking. For a significant difference between presentation and gender, the value of $\mathrm{p}$ is 0.07 , higher than the value of $\alpha=0.05$. Hence, the null hypothesis is accepted. It showed that there is no significant difference of $\mathrm{p}>0.05$ between gender and presentation. This implies that the presentation is determined by gender. The mean for male (3.70) is lower than the mean for female (3.92) and this showed female better in presentation. The result also shows the same for the significance differences between the role play with gender, the value of $\mathrm{p}$ is 0.06 , higher than the value of $\alpha=0.05$. Hence, the null hypothesis is accepted. It showed that there is no significant difference in the level of $p>0.05$ between gender and role play. This implies that the role play is determined by gender. The mean for male (3.65) is lower than the mean for female (3.89). However, for significant differences between group discussion and gender, the value of $\mathrm{p}$ is 0.00 , which is lower than the value of $\alpha=0.05$. Hence, the null hypothesis is rejected. This shows that there are significant differences in the level of $\mathrm{p}<0.05$ between the group discussion and gender. This implies that the discussion is determined by gender. The mean for male (3.55) is lower than the mean for female (3.85). Thus, female also performed better in group discussion compared to male.

Another four analysis were analyzed to meet the second objective of the research which is to relate the four communicative learning teaching activities (speaking, role-play, presentation and discussion) with the achievement of MUET speaking in Maahad Johor. Based on the questionnaire, the questions given have been categorized into speaking activities, presentation, role-play and group discussion. The number of questions and its' category can be seen in Table 2 below

Table 2 Number of questions in questionnaire according its' category

\begin{tabular}{|l|l|}
\hline \multicolumn{1}{|c|}{ CATEGORY } & \multicolumn{1}{c|}{ NUMBER OF QUESTIONS } \\
\hline Speaking Activities & $1,2,3,6,8,10,11,13,20,31,34,37,38,39$ and 40 \\
\hline Presentation & $7,14,16,17,18,19,21,22,23,24$ and 26 \\
\hline Role Play & $5,9,27,28$ and 29 \\
\hline Group Discussion & $4,12,15,25,30,32,33,35$ and 36 \\
\hline
\end{tabular}

Based on the Pearson correlation analysis results, the value of $\mathrm{p}=0.962$, which is more than the value of $\alpha=0.05$. Hence the null hypothesis is accepted. This shows there is no significant relationship between speaking activities and MUET speaking. The strength of Pearson 
correlation (r) is -0.006 which indicates the relationship is inversely proportional and the strength of relationship is weak. The null hypothesis similarly accepted for presentation which shows the value of $\mathrm{p}=0.901$. Thus, the strength of Pearson correlation (r) is 0.015 which shows a direct correlation with a weak relationship. Pearson correlation analysis result also shows there is no significant relationship between role play with MUET with the value of $p=0.760$. The strength of Pearson correlation (r) is 0.037 , which shows a direct correlation with a weak relationship. Similarly, the value of $p=0.788$ for group discussion shows there is no significant relationship between group discussion with the achievement of MUET speaking. The strength of Pearson correlation ( $r$ ) is -0.033 which indicates the relationship is inversely proportional and the strength of relationship is weak. Thus, the analysis of the questionnaire shown that speaking activities has no direct relationship in determining the achievement of MUET speaking based on statistical data.

\subsection{Qualitative Finding}

Based on the interview sessions with four respondents, it is found that all the respondents able to give respond but their problem have been seen clearly in sentence structures. They responded positively in all the speaking activities but the improvement of language cannot be seen during the interview session. This verifies the result of questionnaire which stated that speaking activities has no direct relationship in determining the achievement of MUET speaking among Maahad Johor students.

Respondents' perception on speaking activities in the class are seen as enjoyable as the respondent A saying that, "of course the activities is enjoyable because I enjoy activities...". Respondent B highlighted that speaking activities is interesting ..."for English class in my class is of course is enjoyable and interesting...". They also perceived that speaking activities build their self-confidence. Respondent D said, "actually about the speaking in the class I think that is enjoyable when give more confidence...". They learn by practising speaking and at the same time they listen to others in the class. All the respondents said that the speaking activities are enjoyable and interesting. It helps them to speak and gain more confident in speaking. All the respondents responded confidently as a result of speaking activities although errors are here and there.

For the perception on group discussion activity, the respondents are asked on how group discussion helps them in improving their speaking. They responded positively as they are sharing their real experiences during group discussion in the class. For them, group discussion activity is improving language usage, enhancement of self-confidence and enrichment of vocabulary. As respondent C said,..." from that we will think what we want to talk what is...and we think there are many vocabularies from dictionaries or from internet or anywhere.

The researcher asked the respondents whether they like to have role play in the class and they need to justify their answer. One respondent honestly said that she does not like to have role play activity. However the other three like to have role play in the class due to the chances of feeling expression, think spontaneously and improve speaking skills. Finally, respondents were asked about the presentation in the class. The three respondents said that presentation in the class help them overcome nervous and build up confident in speaking Referring to their interview session, the researcher found out that all the respondents learn something when their friends are presenting in front of the class. Some of the skills are facial expressions, body language and emotion during presentation, practising new words and improve listening skills.

\subsection{CONCLUSION}

Communicative learning teaching (CLT) is very important in educating students in speaking. It cannot be denied that various speaking activities such as presentation in front of the class, role play and group discussion determine students' performance in speaking. As the aim of this study is to determine the effectiveness of oral activities conducted in the classroom through communicative learning teaching activities such as presentation, role play and group discussion among Maahad Johor students, several activities were implemented for specific time to examine if these activities provide relationship in MUET Speaking achievement among students in Maahad Johor. These studies have revealed that the occurrence of the implementation of those speaking activities among Maahad Johor students is a good practise in students but then have not been proven directly in their achievement. However, it still has flaws that can be improved from time to time in order to produce Malaysian students with a good second language.

\subsection{RECOMMENDATIONS}

As the result of the overall study conducted, the researcher has proposed some suggestions that would help improved the level of English especially speaking through creative activities for Maahad Johor students. These suggested actions can be implemented by a particular group to ensure their success. Professional leadership and governance as the head of school is important as they need to give their attention more on the achievement of MUET candidates. School factors like conducive environment, concentration on teaching and learning, school and class size and MUET teachers itself play important roles in improving students proficiency in MUET speaking component.

It is hoped that further study and research have a larger scale of study that would involve students from different schools but have the same background of education in enhancing students' oral competency. The scope for further study is the application of the internal components involving the whole schools as students, teachers, school administrators and other school community who was with the success of the education system itself. The researcher also suggests using another instrument or perhaps a more flexible evaluation where future research could determine various aspects contributing in improving speaking more easily and effectively. By using a variety of instruments such as teaching aids, sound system and various scopes of course, the result will be more meaningful and significant. 


\section{References}

Amizura Hanadi Mohd. Radzi, \& Zaiton Abdul Majid. (2003). To Improve The Students' Skill To Interrupt The Discussion In Order To Take Turn To Speak For Task B in MUET (800/2) Speaking. Prosiding Seminar Penyelidikan Pendidikan Kebangsaan 2003, 197-206.

Atkinson R.L. (1996). Hilgard's Introduction to Psychology.United States of America: Harcourt Brace

Best. J.W. Kahn. (1989). Research In Education. (6th Edition). New Jersey : Prentice Hall.

Brown, Doughlas. 2001. Teaching by Principles: An Interactive Approach to Language Pedadgogy. New York: Logman.

Brown, Gillian and Yule, George. 1999. Teaching the Spoken Language. Cambridge University Press

Chan, S. H., Tan, H. (2006). English for Mathematics and Science: Current Malaysian Language-in-Education Policies And Practices. Language and Education, 20(4), $306-322$.

Creswell, J.W., (2012). Educational Research. University of Nebraska-Lincoln. Pearson.

Hafiza Aini Bte Hassan. (2006). The Use of Genre Analysis in Developing Speaking Skills in a MUET Classroom Context. Master Dissertation. Universiti Teknologi Malaysia;

Harmer, Jeremy.1998. How To Teach English: An Introduction To The Practice Of English Language Teaching. New York: Logman

Huang, Shenghui C. (1998). Senior High School Students' EFL Learning Beliefs: A Site Study. In The Proceedings of the Seventh International Symposium on English Teaching, 477-485. Taipei, Taiwan: Crane.

Hughes, Rebecca. (2006). Spoken English, TESOL, and Applied Linguistics: Challenges for Theory and Practice. Great Britain: CPI Antony Rowe

Kleinsasser, R. C., \& Sato, K. (1999). Communicative language teaching (CLT): Practical Understandings. The Modern Language Journal, 83(4), $494-517$.

Legal Research Board. (2002). Akta Pendidikan 1996 (Akta 550) \& Peraturan Yang Terpilih : hingga 15 Ogos 2002. Kuala Lumpur : International Law Book Services. Littlewood, William. (2002). Communicative Language Teaching. Cambridge University Press

Majlis Peperiksaan Malaysia (2012) Laporan Peperiksaan STPM \& MUET 2011. Penerbitan Pelangi Sdn. Bhd.

Malaysian Examinations Council. (2006) Regulations, Test Specifications, Test Format And Sample Questions: Chief Executive, Malaysian Examinations Council

Matsuura, H., Chiba, R., \& P. Hilderbrandt. (2001). Beliefs About Learning And Teaching Communicative English in Japan. Japan Association for Language Teaching, 23(1), 69-82.

Md Hasbi Bin Hj Md Yunus. (2009). Kajian Kategori Masalah Di Kalangan Pelajar Tahun Satu Yang Tinggal Di Kolej Jaya Dan Kolej Semarak Universiti Teknologi Malaysia, Kuala Lumpur. Tesis Sarjana Pendidikan Bimbingan \& Kaunseling. Skudai : Universiti Teknologi Malaysia.

Mohd Najib Abd. Ghafar. ( 2003 ). Kaedah Penyelidikan Pendidikan. Johor Darul Tadzim : Penerbit UTM

Mohd Najib Abd. Ghafar. (1999). Penyelidikan Pendidikan. Johor darul Tadzim : Penerbit UTM.

Mohd. Azizi Yahya. Jamaluddin Ramli. Yusof Boon. Abdul Rahim. (2007). Menguasai Penyelidikan Dalam Pendidikan. Selangor : PTS Professional.

Mohd. Majid Konting. (2005). Kaedah Penyelidikan Pendidikan. Kuala Lumpur. Dewan Bahasa Dan Pustaka.

Nunan, D. (1991). Communicative tasks and the language curriculum. TESOL Quarterly, 25(2), 279-295.

Richard, Jack C and Rodger, Theodore S. 1999. Approaches and Method in Language Teaching: Communicative Language Teaching. Cambridge University Press Richards, J., \& T. Rogers (1986). Approaches and Methods In Language Teaching. Cambridge: Cambridge University Press.

Savignon, J. S. (2002). Interpreting Communicative Language Teaching: Contexts And Concerns In Teacher Education. New Haven, London: Yale University Press. Savignon, S. J. (1991). Communicative Language Teaching: State Of The Art. TESOL Quarterly, 25(2), 261-277 